\title{
Introduction: women and transnational organized crime
}

\author{
Jana Arsovska • Felia Allum
}

Published online: 18 May 2014

(C) Springer Science+Business Media New York 2014

Giulia is a pretty Southern Italian woman in her forties. She has long brown hair, piercing dark eyes, is immaculately dressed in nice clothes and clutches a Louis Vuitton handbag. Francesca is younger, in her thirties, has blond hair, lively blue eyes and lots to say. But they both look sad and uneasy. Their faces reflect the experiences, the sorrow, the hardship of their past lives, what they have left behind and perhaps, their complex present. These two women are "Camorra women", ${ }^{1}$ women who have lived with the Camorra but today are state witnesses.

Giulia was the partner of an important boss of the Casertano region whom she met at the age of 13. She was "his children's mother" and eventually got drawn into the clan's activities. Because of restrictive prison conditions for Mafia bosses in Italy (art. 41 bis prison regime), she became a vital and active messenger between the boss in prison and his clan on the outside. She was respected as a women but totally subordinate to the men: in her own words, a woman "must do what they say, when they say, what you can do, what you can't do..." (Allum 2012a). She adds that when she explained her reasons for turning state's witness to one of her daughters, disapproving of her mother's decision the daughter replied 'You are now dead for me'.

Francesca, on the other hand, took over the management of slot machines to help her father who was a local boss in Santa Maria Capua Vetere. She became an efficient and fearless manager because as she argues "you might be the daughter of..., the wife of... but after a while you can do it alone, especially when the men are in prison. Why is it that the Camorra is still so strong with all those leaders in prison?" (Allum 2012b). But she explains that she made her decision to collaborate with the State specifically to save her daughter from a criminal life and give her a possible alternative future.

These first hand accounts demonstrate how women today are active in a whole range of Camorra activities and roles; from messenger, to enforcer to decision maker. The Italian National Anti-Mafia Directorate (Direzione Nazionale Antimafia) in its 2013 Annual Report acknowledged for the first time the role of women in Camorra activities; in particular, how

\footnotetext{
${ }^{1}$ Not their real names.

J. Arsovska $(\bowtie)$

John Jay College, New York, NY, USA

e-mail: jarsovska@jjay.cuny.edu

F. Allum

Department of Politics, Languages and International Studies, University of Bath, Bath, UK

e-mail: f.s.allum@bath.ac.uk
} 
women took on leadership roles when their husbands and partners were sent to prison (2014: 93-4). Indeed, in 2013, there were five Camorra women ${ }^{2}$ detained under the Italian art. 41 bis prison regime for their leadership roles and involvement with the Camorra.

We can conclude that women are no longer passive actors, as once believed or perceived; yet the question remains as to the extent of their active engagement and involvement in criminal activities. It is important to note that, traditionally, criminology has treated women's role in crime - particularly organized crime - with indifference. Only a few scholars have tried to study the involvement of women in organized crime activities and this focus has overwhelmingly been on the Italian Mafias and their traditional, mainly local, criminal roles and activities.

This special issue of Trends in Organized Crime on "Women and Transnational Organized Crime" brings together contributors from academics that are analyzing the involvement of women in a variety of transnational organized crime markets, including human and drug trafficking, across time and socio-cultural space. It goes beyond the Italian Mafias.

\section{Debating female criminality}

Some of the earliest works on female criminality suggested that criminal women are abnormal and that the female anatomy is inferior to their male counterparts (Lombroso and Ferrero 1895). Over the years, this led to the development of a feminist critique on the accumulated wisdom of female offenders. In fact, in the past five decades attempts in various fields have been undertaken to explore possible relationships not only between sex and crime, but also gender and crime. Some studies from the 1970s have focused on the relation between the emancipation of women and their increased involvement in masculine and economic crimes (Simon 1975; Adler 1975), while others have argued that power differences between men and women have led women into "powerless" types of crimes such as prostitution and the neglect of children (Messerschmidt 1986). Radical feminists have asked whether crimes by and against women were shaped by gender inequality inherent in "patriarchy"? While some argued that patriarchal controls prevented women from deviating (Heidensohn 1985), others stated that the failure of patriarchal society to deliver "promised deals" to women removed controls which had prevented them from offending (Carlen 1985).

However, despite some research in this area, up until the early 1990s, one specific aspect in the study of crime was regularly ignored or dismissed - the presence and role of women in criminal organizations. Indeed, if one had looked closer, it would have been very difficult to find their consistent presence for two interconnected reasons: Firstly, because of the limited access to reliable empirical material in the field of organized crime; and secondly, because of the ongoing perception that tends to draw stereotypical imagery of women in organized crime as appendixes to their male counterparts, as their mistresses and as sex objects.

\footnotetext{
${ }^{2}$ Camorra women in prison under the Italian 41 bis regime: Partorina Arcone (clan Longobardi, Pozzuoli, since 2011); Maria Buttone (clan Belforte, Marcianise, since 2013); Teresa De Luca (clan De Luca Bossa, Ponticelli, since 2010); Esterina Pagano (clan Casalesi since 2011); Concetta Zarrillo (clan Belforte, Marcianise since 2013).
} 
Many scholars have argued that organized crime is a topic beyond objective measure. Indeed, it is difficult to conduct reliable empirical research on an entity concealed in the criminal underworld. Only rarely can law enforcement officers and researchers observe the activities of a criminal group directly. Scholars have realized that studying and measuring female criminality focused on crime statistics also failed to highlight the extent of violence and crime, which goes unreported - or is over reported-for numerous reasons including, men's cultural reluctance to address being victimized; women's lenient treatment by the criminal justice system due to "chivalry" (Pollak 1961); or female offenders' subjection to double jeopardy in that they are on trial for the crime they commit and for their femininity (Heidensohn 1985; Smart 1977). Therefore, women's presence in organized crime activities was not systematically recorded in official documents or investigated and when it was, it was never publicized.

Past scholars concluded that organised crime was sexually segregated because when the stakes were high and the risks were great, women were more likely to remain in gendered roles as wives or mothers, disconnected from crime (Steffensmeier and Allan 1996); they were not meant to be risk takers because they were socialized towards greater conformity (Anderson 1988). Clare Longrigg recalls 'a 1983 court ruling in which a Palermo judge declared that women could not be guilty of money laundering because they were not autonomous and were anyway too stupid to take part in "the difficult world of business" (1998: xv), when it was clear that women often had an active role at different levels of the organization (Puglisi 2005). The "assistant roles" that women sometimes hold in the Italian Mafia, were perceived as unsophisticated and therefore not punishable by law, which further highlighted the gender biases and expectations of male and female relationships in criminal networks. Fiandaca (2007) argued that stereotypes have greatly influenced Italian judges for a long time and made Mafia women, who were regarded as passive subjects dominated by their Mafiosi menfolk, insusceptible to penalty. Stereotypes and images of women as weak female figures reinforced the notion that women could not make independent business decisions nor be violent.

Similar stereotypes have been common in other regions around the world. In the same regard, Rossi (2007) confronts the insufficient attention paid to Argentinean women involved in organized crime, who are found to have ties with criminal organizations. Public prosecutors in Argentina have expressed that women are deemed the "weaker gender" and not properly equipped or trained to take substantive roles in organized crime similar to men; thus, the attention is focused on the male who is naturally identified as the instigator. For this reason, Rossi argued, it is rare that women are in charge of criminal organizations, and if they happen to take part, it is often in crisis situations, where the male boss is in prison, a fugitive, or otherwise unable to fulfill his role.

However, since the late 1990s, police agencies across the world, including INTERPOL and Europol, have noted that on the one hand, women have gained more prominent roles in transnational organized crime networks, in particular human trafficking (Aronowitz et al. 2010) ) $^{3}$ and, on the other hand, the number of female offenders

\footnotetext{
${ }^{3}$ For example, in Netherlands, in the period 2000-2008 females accounted for 15-27\% of the suspects in any given year with a high of $27 \%$ in 2000 to low of $15 \%$ in 2008. Similar pattern could be observed for convicted offenders (from $23 \%$ in 2000 to only $10 \%$ in 2008). In Germany, according to Bundeskriminalamt Menschenhandel Bundeslagebild (2009) from 777 suspects $77 \%$ men and $22 \%$ women (gender was not specified in $1 \%$ of the suspects). In the United States, according to BJS (2010) $18.4 \%$ of confirmed suspects of sex trafficking and $24 \%$ of confirmed suspects of labor trafficking are women.
} 
is substantial and growing (Europol 2011). According to the United Nations Office on Drugs and Crime (UNODC) the roles of female offenders in human trafficking networks have become central (UNODC 2009: 47). ${ }^{4}$ The 2009 UNODC study on human trafficking was conducted in 155 countries but information on gender was available in 46 countries. The results indicated that in four countries, women comprised less than $10 \%$ of those investigated/prosecuted for human trafficking. In 28 countries, women ranged from 10 to $50 \%$ of those investigated/prosecuted; and in 14 countries, women comprised over $50 \%$ of those investigated/prosecuted. For instance, according to the National Agency for Prohibition of Traffic in Persons and Other Related Matters (NAPTIP 2006), $60 \%$ of prosecuted persons in trafficking cases are women and $50 \%$ of convicted traffickers are women.

These "women-criminals" have acted as "partners in crime" and "organizers"-which refers to the strategic planning of the trafficking operation, from the recruitment of victims to their exploitation, and the control over the finances. ${ }^{5}$ This alleged shift from being "passive victims" and "supporters"- usually subordinates to the male criminals who (are compelled to) carry out specific tasks, for example, collecting money or controlling other women, in order to survive - to being "partners-in-crime" or "madams" (independent businesswoman $)^{6}$ implies that women's roles are "evolving" in criminal networks and consequently they are becoming more active and visible in various criminal markets. However, this assumption requires more systematic and in-depth analysis.

Several theories have emerged to explain the involvement of women in organized crime activities. Some, for example, have focused on women "emancipation" and increased opportunities, while others have interestingly suggested that there might be a correlation between violence and women active in organized crime; in other words, with less violence, there might be more flexibility in the organization and more women coming into management roles (see Savona and Nataoli 2007; Zhang et al. 2007). Scholars in general have often tried to apply theories that initially have focused on the role of women in the Italian Mafias, although, as the articles in this special issue will illustrate, different approaches may be required to study less traditional forms of organized crime.

\section{Women and the Italian Mafias}

In Italy, this emerging research area became important in the early 1990s thanks to a combination of factors: the coming of age of young women researchers and judges

\footnotetext{
${ }^{4}$ See UNODC Global Report on Trafficking in Persons (2009).

${ }^{5}$ See the study by Siegel and de Blank (2010) where the roles of women are defined and discussed (e.g. supporters, partners in crime and independent businesswomen/madams/organizers).

${ }^{6}$ See, e.g., O'Kane $(1992,52)$ : Historically, women have been restricted to the areas of saloon keeping, fencing, prostitution, brothel proprietorship, small-time gambling operations, narcotics trafficking operations, and numbers rackets. Their criminal enterprises fell under the control and sponsorship of the larger all-male ethnic mobs and the females involved in these were few indeed. Among the Irish and the Jews in the nineteenth century, a number of women gained local notoriety: Roseanna Peers, "Battle Annie," "Sadie the Goat," and "Hell Cat Maggie," among the Irish; Marm Mandelbaum and her associates "Black" Lena Kleinschmidt, "Kid Glove" Rosie, Sadie Chink, Rosie Hertz, and Spanish Mary, among the Jews. Notable Chinese and Italian female mobsters other than prostitutes or brothel owners are virtually nonexistent in the historical and sociological literature; black female criminals in the 1920s receive some notoriety, particularly in the Harlem numbers racket (e.g., "Madam Queen" Stephanie St. Clair). Overall, however, very little is known about the active roles of women in organized crime prior to the early 2000 s.
} 
trying to understand the dynamics of women's presence and activities in Mafias; a change in the Italian society which started to accept that women could be fully independent and autonomous from their menfolk; and, the introduction in 1991 of a state witness protection program. This law allowed Mafiosi to collaborate with the State in return for leniency. It was also helpful for researchers because it produced accessible material for the first time; often detailed accounts by former Mafiosi of the active role of women.

There are four main Italian mafia-type groups present and active in Italy: the Sicilian Mafia, the Calabrian 'Ndrangheta, the Neapolitan Camorra and the Puglese Sacra Corona Unita. Although they have contrasting origins and are based in different regions, today they can be defined by their common features: "mafia-type criminal organisations make up a secret society, with specific bonds of loyalty and a welldefined hierarchy of control, and act in pursuit of gain, reputation and security," their power is based on "excercising violence [...], exploiting traditional codes and manipulating social relationships" (Sciarrone and Storti 2014: 42-43). They combine on the one hand "an 'organisation for illicit trafficking' which makes it an 'enterprise' that operates between the legal and illegal markets" with "an organisation for control of the territory' of the local socities in which they are embedded" (p. 43). Thus, Italian mafias are simultaneously secret societies embedded in a local territory and modern, international multi-million pound enterprises. Despite these similarities there are differences partiuclarly with respect to the role of women.

Two main schools of thought have evolved in this area to analyse and explain the role of mafia women: one, that acknowledges the ambigious but participant role of women (Siebert 1996; Dino 1998, 2007, 2011; Ingrasci 2007; Allum 2007) and the other, that argues that Sicilian women are not active because they cannot officially join Cosa Nostra (Pizzini-Gambetta 2006).

The first school of thought argues that women are fully involved in "male only Mafias" (Siebert 1996: 13) but in subtle ways. This is predominately a cultural approach. Renate Siebert (1996, 2003, 2007, 2011) developed a highly intricate analysis about Italian Mafias and their relationship with women through the prism of gender. She uses "a gender approach" to argue that "the Mafia is a secret society which by definition excludes women" (1996: 13) where "the exclusion of women seems a fundamental element in the cohesion of the group" (1996: 7). And, yet, while women are formally excluded they are in fact "central to the Mafia's deployment of its signoria [power] at a local level, not only in terms of the continuation of its day-to-day dominion but also of its immediate control and administration of illegal activities" (2003: 45). In other words, Mafia women live a dual existence: ignored and adored on the one hand, and on the other, a stable support system, which is systematically and functionally used by men for the everyday activities of the clan.

Alessandra Dino, who also sees women as being fully involved in the clan's activities, argues that "in reality, women have always been present in Mafia contexts, whether carrying out explicitly criminal roles or providing indispensable daily support" (2012: 323). She believes that they have a "submerged centrality" (Principato and Dino 1997 ) but that with general social processes of emanicipation, Mafia women have gained "a temporary delegation of power" in the economic sector in particular. However, the power of deciding the organization's strategies stays for the moment in the hands of the men (Principato and Dino 1997; Siebert 2003). Following on from 
these considerations, Ingrasci $(2007,2011)$ developed the idea of "pseudo-emancipation" to explain the role of women in the Calabrian "Ndrangheta. She suggests that they do make decisions and undertake acts of violence but remain fundamentally subordinate, submissive and under the control of their men, husbands, brothers, brother-inlaws. Monica Massari $(2007,2011)$ noted similar patterns for the Sacra Corona Unità.

Camorra women have always been seen as slightly more "independent" than their Sicilian, Calabrian and Puglese counterparts; perhaps because during the 1950s some strong women such as Pupetta Maresca were active and visible in the national news (Allum 2006, 2007). However, Neapolitan researchers have also adopted the notion of "emancipation" to see whether it could possibly explain the situation today, even though as Gabriella Gribaudi (2011) noted, women have always been present on the streets, selling goods or as look outs. The term "emancipation" is tested but considered rather unhelpful because women may be active and violent but they remain fundamentally subordinate to their men who continously call the shots as Zaccaria (2011) has shown.

Women gain access to leadership roles in the Camorra not out of merit or emancipaton in the clan but because of their blood ties and the respect they have gained from them. For example, Raffaele D'Alterio was arrested in 2013 for her involvement in her husband's murder and having control over the region of Qualiano (Procura della Repubblica, Comunicato Stampa 2013) but she was able to do this because of who her new partner was, her brother's support and the recognition and legitimacy she had gained from her different relationships with men.

Another good example is the role of women in the Secondigliano alliance's counterfeit activities during 1990-2002. In Graph 1, the larger upside down triangles represent the women involved in this transnational scam. The graph clearly shows

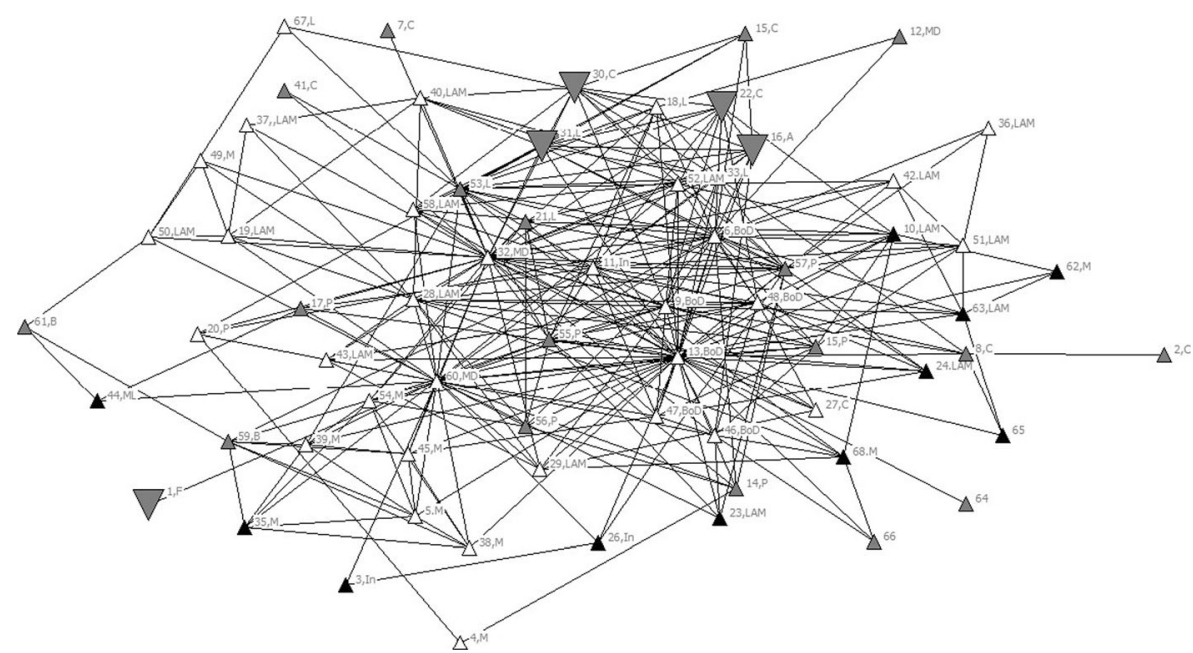

Graph 1 Women in the Secondigliano Alliance Counterfeit Network (1990-2002 (This graph was elaborated on the basis of a police document (Questura di Napoli, Squadra Mobile, Informativa di reato a carico di Aiello Carmela +62 , Nr.02002/Sq.Mob.Sez.3 ${ }^{a}$.Napoli, 22/5/2002.) and shows who spoke to who. It makes visible the role of five women within the counterfeit scam. The authors wish to thank Alessandro Colletti (University of Rome 3, Italy) for having elaborated this social network for them.)). Key: Triangle: men. Upside down triangle: women 
how there were few women involved, and although they occupied positions of less strategic importance than most of the men they were directly connected to, their roles and ranks were determined precisely by their blood ties to these leaders. The five women here all played vital support roles to the criminal activities because they were either sisters or wives to active Camorra members. Their roles ranged from a top leadership position to a simple frontname in order to facilitate money laundering. They were trusted and relied upon not so much for their skills, knowledge and resources but because of who they were related to. It is also interesting to note that although this was a cross border activity, none of the women travelled abroad. More research in this area clearly needs to be undertaken.

Rather to talk of "emancipation," it might be more useful to look at Camorra women as "a reserve army" called upon and available when necessary, particularly when the main leaders are away. They behave like their professional counterparts using and ordering violence which many scholars do not acknowledge (see Beare 2010). This school of thought focuses on the complex role of women and seeks to analyse it within the cultural context of mafia-type organisations that combine features of secret societies and a business enterprises all in one.

The second school of thought is one which analyses gender norms in Mafias and asks whether women can be involved in such activities if they are not official members. This is based on a Rational Choice approach. Valeria Pizzini-Gambetta (2006) questioned the role of women in the Sicilian Mafia and suggests that although there may have been changes in Sicilian society, in the culture and the legal system, women are still not involved in the activities of the Sicilian Mafia. This she makes clear when she argues that "rather than a political system, Cosa Nostra is an organization and people become members of it. Thus, in order to exit, one should first enter and, as all evidence points out, no woman has yet become a member of the Mafia [...]" (2006: 359). She maintains that it is not women who are becoming more involved in criminal activities but that it is the immunity behind which they have been hiding that is coming down: "women connected with Cosa Nostra are becoming more visible, although they may still be involved as little as they were in the past in running the organization" (2006: ibid).

In a later article on Camorra women, analysing Saviano's potrayal of women in Gomorrah (2009), she can no longer make the argument about joining the organisation because there exists no formal affiliation ritual for the Camorra, she highlights the important role of men in their clans, arguing that without men, women would not access any of these roles. And this is not wrong. However, her argument is not so much about how women "can make it" in the Camorra, and how an increasing number of women are involved in Camorra activities but to show that they cannot make it, and that they are not becoming more important than before because ultimately, men use violence and women do not. She concludes that "as long as women need to delegate violence I doubt that matriarchy will replace patriarchy in mafia or camorra groups since violence and command cannot be parted in that industry" (2009: 270-1). We still know relatively little about Camorra women's use of violence and they may not be as foreign to violence as one thinks. For example, it is believed that during the recent bout of violence in the province of Naples, women killers have been employed to lure their victims to their death (Di Caterino 2014). Regardless of whether women use violence or not, they are still an active force in the Camorra and involved in some important 
decisions in the economic or military sector but we also know relatively little about women's role in the Camorra's foreign operations.

Once again, how organized crime is viewed and analyzed depends on the theoretical lens that one adopts to interpret these phenomena. This means that this debate on the role of women in the Italian Mafias remains somewhat ideological because of the lack of strong empirical data which would give us a good sense of the full extent of their involvement.

\section{Multiculturalism and diverging views}

The question, however, remains whether we can apply the assumption that women continue to only play roles dependent on male mentorship and supervision to culturally different regions and to various types of transnational organized crime activities? It is important to study whether the structure and culture of mafia-type organizations, such as the Italian Mafias, is largely responsible for the dependency of Italian women to male mentorship. What type of roles do women hold in more fluid and flexible transnational organized crime groups that are less culturally bound and more about economic transactions? What do scholars have to say about the role of women from different socio-cultural spaces in various transnational organized criminal markets?

It is important to acknowledge that, in its most literal sense, "Mafia" is a collective term meant to describe the original Italian crime enterprise (the Sicilian Mafia) that has existed both in Italy and then in the United States, with a smattering of influence elsewhere. But as shown above, today, the term often is intertwined with other forms of organized crime. This overuse of the term has made it difficult to define a mafia group, mafia-type organization and organized crime, in general. Giovanni Falcone, the antiMafia judge murdered by the Mafia in 1992, objected to the conflation of the term "mafia" with organized crime in general. In his view, the term mafia-type organizations is used to distinguish the uniquely Sicilian Mafia from other criminal organizationssuch as the Camorra, the "Ndrangheta, the Sacra Corona Unità - that are structured like the Mafia, but are not the Mafia (Falcone and Padovani 1993).

There are nevertheless organized crime groups that are more entrepreneurial and less hierarchical, political and cultural than the stereotypical mafia, or mafia-type organizations in general. These groups are not essentially interested in politics and do not aspire to govern others. Transnational organized crime involves the planning and execution of illicit business ventures by groups or networks of individuals working in more than one country. The UN Convention on Transnational Organized Crime (2000) contains a more modern definition of "organized criminal group" to allow for a broader applicability of the Convention to new types of crime that emerge constantly as global, regional and local conditions change over time. Article 2(a) of the Convention writes:

- a group of three or more persons that was not randomly formed;

- existing for a period of time;

- acting in concert with the aim of committing at least one crime punishable by at least 4 years' incarceration;

- in order to obtain, directly or indirectly, a financial or other material benefit. 
Since most "groups" of any sort contain three or more people working in concert and most exist for a period of time, the true defining characteristics of organized crime groups under the Convention are their profit-driven nature and the seriousness of the offences they commit. According to the Convention, the term "transnational," covers not only offences committed in more than one State, but also those that take place in one State but are planned or controlled in another. Also included are crimes in one State committed by groups that operate in more than one State, and crimes committed in one State that has substantial effects in another State. "Transnational organized crime" from this perspective encompasses virtually all profit-motivated serious criminal activities with international implications. So in reality the traditional Italian Mafias (mafia-type organizations) and transnational organized crime groups are not necessarily the exact same phenomenon, and for this reason the roles of women in these structures may vary, and different theories may explain the involvement of women in transnational organized crime networks better.

For example, some theories suggested that successful female organized crime figures take their gender into account to make cognizant choices about what, when and how to deal. Fleetwood (2014) who studied female crack cocaine dealers in England argued that dealing strategies were a response not solely to the gendered nature of the drug market but also to women's gendered social positions, relationships and identities. Performing respectable femininity was a key strategy for keeping out of trouble. So the notion of "doing gender" is something that has attracted considerable attention in the limited literature on women and organized crime.

One vivid example of "doing gender" and using femininity within contemporary transnational organized crime is the case of the Pink Panthers - a name given by INTERPOL to an international jewel thief network, which is responsible for some of the most audacious and glamourus thefts in criminal history. They have targeted several countries and continents, and in a period of six years (after 2000) the Pink Panthers robbed 120 stores in 20 different countries (Allen 2009; Fleishman 2009). Some law enforcement agencies suspect that the group is responsible for over USD 500 million in bold robberies in Dubai, Switzerland, Japan, France, Liechtenstein, Germany, Luxembourg, Spain and Monaco (Samuels 2010). INTERPOL estimated that there are several hundred thieves in the group, and that many come from Serbia. However, other sources say the gang is suspected of having at least 60 members, around 30 of whom are thought to be from Montenegro (Samuels 2010). Interestingly, the women in this group appear to hold some of the most important positions and the work of the thieves depends on the work that the women do prior to the burglaries.

In an interview with Havana Marking, director of the 2013 documentary Smash and $G r a b,{ }^{7}$ one of the key members of Pink Panthers explained: "The women in the Panthers have to be exceptional... You can have only one in each gang, and we have higher requirements for the women because they have the leading roles. They have to do the main job... They enter, they record, and they bring the plan. That means, the woman has to be intelligent, she has to be beautiful and she has to love money." In

\footnotetext{
7 Smash \& Grab: The Story of the Pink Panthers is a 2013 documentary by Havana Marking based upon the international jewel thief network called the Pink Panthers. The movie had a limited release on Jul 31, 2013 and had a wider release in the United Kingdom on September 27, 2013. Short version of the documentary is available online: https://www.youtube.com/watch?v=DTLy2zNwxLQ
} 
another interview, one of the key female players in the group reported that the men are not able to do anything without the women, and that the women understand that they have the most important job in the network. "Not anyone can do this job. You must be born to do it. You must firstly trust in yourself. Because if you are weak, you can't do it...I was extremely good looking. Although I had frequent transformations. Very frequent. The guys do a lot of the work but they also need a woman on their team. Everyone always thinks is the men, men, men, but without a woman nothing will be done." However, the Pink Panther madona also noted that she joined the group because of her boyfriend, and she dreams of living a normal life one day, together with the love of her life.

Another example of the capabilities of women to get involved in high risk activities linked to organized crime is that of Albanian organized crime figure Alket Rizaj and his girlfriend Soula-Aspasia Mitropia. In Hollywood-style helicopter escapes, Alket Rizaj, Vassilis Paleokostas and Nikos Paleokostas broke from the Korydallos highsecurity prison in Greece. Alket Rizaj, an Albanian immigrant, has been involved in robberies, drug smuggling and contract killings in Greece since the early 2000s. He was convicted for murder in Greece and then escaped for the first time from Korydallos prison in 2006 together with Vassilis Paleokostas, a Greek bank robber and kidnapper (Nellas 2009). Nikos Paleokostas was recaptured and is still in jail. Rizaj was also recaptured in 2006, while Vassilis Paleokostas was captured in 2008.

Then, Alket Rizaj and Vassilis Paleokostas escaped for a second time in 2009 from the same prison. The two robbers escaped from a high-security prison by scaling a rope ladder to a hovering helicopter amid a gun battle with guards. The rope ladder was thrown to them by Rizaj's girlfriend, Soula - a partner in crime. Guards on the ground opened fire and the woman fired back with an automatic rifle. Rizaj's girlfriend is known to have helped with the escape in 2006 as well. An elderly couple found the helicopter abandoned near a highway north of Athens. The pilot was bound and gagged, with a hood over his head. He told police the helicopter was chartered by a couple who said they wanted to go from the town of Itea in central Greece to Athens. The couple threatened him with an AK-47 rifle and a grenade and forced him to fly to the prison (Nellas 2009). However, was Soula involved in these risky criminal activities mainly because of her boyfriend, or is she a sensation-seeker that also loves money? Are emotions important for explaning the role of women in transnational organized crime networks? And do theoretical explanations vary across socio-cultural space?

This special issue is composed of six articles and two book reviews that focus primarily on the relationship between women and transnational organized crime activities. We have concentrated on non-Italian women in order to push further the discourse about women's involvement in economic activities. The articles explore various sociological and criminological theories, some of which study variations in socialization across regions and countries as related to gender roles. The articles suggest that culture, economic conditions and the socio-political environment could have a significant impact on people's preferences and wants but also that individual preferences can be dependent on age, gender, ethnicity, race, and other characteristics. Some articles explore issues such as emancipation, social embeddeness and gendered markets while others acknowledge that different racial and ethnic groups may have different norms for femininity and masculinity and thus act differently in certain situations. 
Traditionally, women were thought to be incapable of participating in the violent or business operations of criminal groups, as well as unable to occupy important positions in criminal structures. The contributions in this special issue paint a different picture; they describe women as capable of committing crimes in a range of transnational economic organized crime activities. The articles also offer unique methodological insights into these highly understudied topics.

\section{The contributions to this special issue}

In the first article, Dr. Edward R. Kleemans, Professor at the VU School of Criminology (University of Amsterdam) in the Netherlands, and Drs. Edwin W. Kruisbergen and Ruud F. Kouwenberg, researchers at the Crime, Law Enforcement and Sanctions Research Division of the Research and Documentation Centre (WODC) in the Netherlands, analyze the role of women in various types of transnational organized crime. They test the gendered market hypothesis by Zhang et al. (2007) that looks at the unusually prominent role of (Chinese) women in human smuggling as a form of organized crime. According to Zhang et al., this higher prevalence of women in human smuggling, compared to traditional drug cases, is due to: the limited role of violence and turf as organizing features of human smuggling; the gender ideologies about work and care giving; and the impact of safety as an overriding concern for clients (see also Savona and Nataoli 2007).

For the purpose of their article, Kleemans et al. collected 150 cases from the Dutch Organized Crime Monitor. The authors studied the role of women in various forms of organized crime, including traditional drug trafficking cases (cocaine, heroine and cannabis) but also trafficking in synthetic drugs, human beings as well as money laundering, fraud and human smuggling. The paper discusses several important theoretical perspectives from the organized crime literature: the gendered markets hypothesis; the social embeddedness of organized crime; and the idea of brokerage. The work breaks new theoretical ground by explaining the reasons behind the active involvement of women in various criminal markets, not only human trafficking.

Annette Hübschle-Finch, in her role as a senior researcher at the Institute for Security Studies in Cape Town from 2002 to 2011, conducted and led research into informal and organized markets in Sub-Saharan Africa. Also, under the auspices of the Max Planck Institute for the Study of Societies in Cologne, Germany, she is currently working on a doctoral research project which investigates the illegal rhino horn market along the supply chain from Southern Africa to Southeast Asia. In her article, she argues that organized crime scholars have paid scant attention to gender and stereotyped roles of women in the commission of organized crime activities. She is focusing on the involvement of women - both as victims and perpetrators - in transnational organized human trafficking, drug trafficking, and rhino poaching operations in southern Africa. The case studies draw on the findings of a 12-country research project on organized crime trends in southern Africa. Her research outputs relied heavily on fieldwork and networking with stakeholders from intergovernmental organizations, law enforcement entities, civil society and academia. Sources also included imprisoned criminals, and members of gangs and organized crime networks. The analysis of police statistics and customs data also formed a key activity in the data-gathering phase. As a means to supplement 
rudimentary official crime data, ad hoc surveys and focus groups were conducted within some constituencies. Information was also gathered from other (informal) sources such as taxi drivers, sex workers, informal traders, drug users, nightclub staff and travellers.

Hübschle argues that the common link of women to organized crime is one of suffering and exploitation. However, one could interpret the data presented by Hübschle in another way so that the role of women appears in a somewhat different light. The case studies presented in her article show that women feature in supporting, managerial and decision-making positions. In some instances, women are self-made criminals; in other cases, they slip into these roles due to the death, sickness or incarceration of a male relative or partner.

Dr. Dina Siegel is a professor at the Willem Pompe Institute for Criminal Law and Criminology at Utrecht University in the Netherlands. In her essay she points out that the last two decades have seen a number of publications showing that women play an important role in transnational organized crime. Their roles have ranged from Nigerian "madams" who occupy key positions in international human trafficking networks, to Mexican female coyotes and leaders of drug trafficking networks in Colombia. Various explanations have been offered for this phenomenon, from the "criminal emancipation" of women to a "criminal gender competition." In her paper, similarly to what we acknowledged in the beginning of this introduction, Siegel argues that women have always been active in organized crime, but that not enough research has been carried out into this phenomenon. The recent focus on the subject has revealed a growing body of evidence to suggest that women have been active as members and leaders of criminal organizations around the world in various periods of history. This evidence, according to Siegel, has cast doubt on the prevailing idea of a "sudden rise" of female power. Siegel takes a somewhat more rational approach to the study and argues that it is not so much equality or inequality between sexes but rather the transnational and fluid opportunities, the changing nature of organized crime and the attractive image of crime (wealth, power and freedom) that seduce women into entering the criminal world to a greater degree.

Dr. Marina Mancuso is a researcher at Transcrime Joint Research Centre on Transnational Crime, at the Università Cattolica del Sacro Cuore in Milan, Italy. In her research, she applied Social Network Analysis (SNA) to a case study to analyze the role of madams in a Nigerian sex trafficking network. The case study referred to women who had been victims of sex trafficking from Nigeria to Italy, the countries that seem to be the crucial points of the West Africa-Europe route. In particular, the study analyzed the police investigation called "Foglie nere" performed by the Carabinieri and coordinated by the Court of Ancona (Italian city in the Marche region). Information on the case came from the arrest warrant issued in 2009. Using relational data on telephone conversations, the main centrality measures were calculated and the author studied how social relations affect the behaviors of the women in the networks. Mancuso argues that the analysis confirms the importance of madams already highlighted by many academics, but surprisingly it also shows that not all madams are equally central in terms of their brokerage positions. Indeed, two different groups of madams are identified according to their betweenness centrality, which is the measure that best reveals the strategic positioning of the nodes within a network.

Dr. Jana Arsovska, Assistant Professor at John Jay College of Criminal Justice and Popy Begum, McNair Scholar currently pursuing her MA studies at Oxford University 
in the UK, compare the roles of women from West Africa and the Balkan region in transnational organized crime activities. The authors investigate how socio-cultural contexts and history contribute to one's position in the criminal network. The assumption that actors do not always behave rationally, in the economic sense, raises the possibility that different people in different social contexts have different perceptions about the probable consequences of a specific behavior. People also develop different perceptions of the risk, effort and reward entailed in criminal behavior. In fact extra emotional and culture specific factors are often so powerful that they seem to make traditional modes of rational decision making inconceivable. By applying a multicultural feminist approach the article argues that femininity is context specific, and therefore a specific group should not define the struggles of women and the causes of female criminality. Among other things, the authors interviewed law enforcement officials, NGO representatives and victims of trafficking.

Finally, Eva Lo Iacono, PhD candidate at the Universita Cattolica del Sacro Cuore in Milan, Italy, attempts to overcome the dominant juxtapositions in the interpretation of trafficking offences: for example, victims vs. offenders and innocent vs. corrupt women. Her case study is on the trafficking of Nigerian women in Italy. The article examines Dina Siegel's vertical mobility theory, Roberto Beneduce's explanation of the "conflicting aspects" of the interpretation of the trafficking phenomenon and the concept of "gray area" as it is defined by Primo Levi. The author argues that one must acknowledge that not all trafficked women in Nigeria identify themselves as a victim and especially not in the sense of an innocent, passive and ignorant individual. She concludes, however, that the characters involved in trafficking may be in intermediate positions between the two opposing figures of the victim and perpetrator, which is why it is difficult to understand when the characters act as independent agents. The conclusions are based on interviews with trafficked persons who attended social rehabilitation programs in Italy and interviews with Italian public officials and nongovernmental social providers working in assisting Nigerian trafficked victims in northern and southern Italy. The author also collaborated in a study on trafficked persons conducted by the International Organization for Migration (IOM).

Moreover, this special issue also contains two book reviews. Dr. Lavorgna from the University of Trento in Italy reviewed Ko-Lin Chin and James O. Finckenauer's new book Selling Sex Overseas. Chinese Women and the Realities of Prostitution and Global Sex Trafficking. She argues that this is an important and well written contribution, which focuses on sex trafficking and prostitution in China-an area where relatively little academic research has been carried out-and challenges the conventional wisdom about sex trafficking. Alice Tregunna, $\mathrm{PhD}$ Candidate at University of Auckland, reviewed the second book discussed in this special issue: Cocaine Cowgirl: The Outrageous Life and Mysterious Death of Griselda Blanco, the Godmother of Medellin by Jennie Erin Smith. Tregunna explains why and how this e-book presents an authoritative account of one of the most infamous female organized criminals in history, Griselda Blanco.

Although the articles presented in this special issue discuss different perspectives on female criminality, some common conclusions emerge. Firstly, it is impossible to utilize one theory of female criminality to explain the variety of trends on women and organized crime across socio-cultural space and markets. Secondly, the stereotypical image of women as victims, sex objects and passive players in organized crime 
networks appear to be passé at the beginning of the 21 st century. Thirdly, more empirical research and theoretical models are required for us to better understand the intricate and varying roles of women that are too often ignored at our peril. The articles in this special issue remind us that gender mainstreaming within scholarly literature and policy research is still in nascent stages, and that criminal justice and social initiatives should pay more attention to the dynamism and multifaceted roles of women in organized crime across the world.

\section{References}

Adler F (1975) Sisters in crime: the rise of the new female criminal. McGraw-Hill, New York

Allen P (2009, June 20) Three suspected Pink Panther gang members arrested in Monaco. The London Daily Telegraph: http://www.telegraph.co.uk/news/worldnews/europe/monaco/5586122/Three-suspected-PinkPanther-gang-members-arrested-in-Monaco.html. Accessed 25 Feb 2014

Allum F (2006) Camorristi, politicians and businessmen, the transformation of organized crime in post-war Naples. Maney, Leeds

Allum F (2007) Doing it for themselves or standing up for their men? Women in the Neapolitan Camorra (1950-2003). In: Fiandaca G (ed) Women and the mafia: female roles in organized crime structures. Springer, New York

Allum F (2012a) Interview with G, Rome, 28 October

Allum F (2012b) Interview with F, Naples, 27 December

Anderson LM (1988) Thinking about women, 2nd edn. Macmillan, New York

Aronowitz A, Theuermann G, Tyurykanova E (2010) Analyzing the business model of trafficking in human beings to better prevent the crime. OSCE \& UN_GIFT. OSCE, Vienna

Beare M (2010) Women and organized crime, paper prepared for research and national coordination organized crime division law enforcement and policy branch, public safety Canada, Report No. 013, 2010, Canada

Carlen P (1985) Criminal women, myths and misogyny. In: Carlen P (ed) Criminal women: autobiographical accounts. Polity Press, Cambridge

Di Caterino M (2014, February 21) Donne Killer nel commando di Caivano che ha bruciato due uomini, Il Mattino. Available at http://www.ilmattino.it/napoli/cronaca/donne_killer_per_uccidere_a_caivano/ notizie/533075.shtml. Accessed 10 Mar 2014

Dino A (1998) Donne, Mafia E Procesi di Comunicazione. Rassegna Ital Sociol XXXIX(4):477-512

Dino A (2007) Symbiolic domination and active power: female roles in criminal organizations. In: Fiandaca G (ed) Women and the mafia: female roles in organized crime structures. Springer, New York

Dino A (2011) Narrazioni al femminile di Cosa Nostra. In: Gribaudi G, Marmo M (a cura di) Donne di Mafia, Meridiana, Rivista di Storia e Scienze Sociali, n. 67. Viella, Roma

Dino A (2012) Women and transnational organized crime: the ambiguous case of Italian Mafias. In: Allum F, Gilmour S (eds) Routledge handbook of transnational organized crime. Routledge, London

Direzione Nazionale Antimafia (2014) Relazione Annuale sulle attività svolte dal Procuratore Nazionale Antimaifa e dalla Direzione Nazionale Antimaifa nonché sulle dinamiche e strategie della criminalità organizzata di tipo mafioso nel periodo 1 luglio 2012-30 Giugno 2013, Roma

Europol (2011) Trafficking in human beings in the European Union. Knowledge Product, Europol Public Information

Falcone G, Padovani M (1993) Men of honour, the truth of the mafia. Warner, London

Fiandaca G (ed) (2007) Women and the mafia female roles in organized crime structures. Springer, New York

Fleetwood J (2014) Keeping out of trouble: female crack cocaine dealers in England. Eur J Criminol 11(1):91109

Fleishman J (2009, July 29) Balkans' Pink Panther jewel thieves smash their way into myth. LATimes.com. Available: http://www.latimes.com/la-fg-balkan-panthers29-2009jul29,0,5933791.story\# axzz2wzF3CdAs. Accessed 10 Mar 2014

Gribaudi G (2011) Donne di Camorra e Identità di genere. In: Gribaudi G, Marmo M (a cura di) Donne di Mafia, Meridiana, Rivista di Storia e Scienze Sociali, n. 67. Viella, Roma

Heidensohn F (1985) Women and crime. Macmillan, Basingstoke

Ingrasci O (2007) Women in the 'Ndrangheta: the Serraino-Di Giovine case. In: Fiandaca G (ed) Women and the mafia: female roles in organized crime structures. Springer, New York 
Ingrasci O (2011) Donne, 'ndrangheta, 'ndrine. Gli spazi femminili nelle fonti giudiziarie. In: Gribaudi G, Marmo M (a cura di) Donne di Mafia, Meridiana, Rivista di Storia e Scienze Sociali, n. 67. Viella, Roma

Lombroso C, Ferrero W (1895) The female offender. D. Appleton, New York

Longrigg C (1998) Mafia women. Vintage, London

Massari M (2007) Women in the Sacra Corona Unità. In: Fiandaca G (ed) Women and the mafia: female roles in organized crime structures. Springer, New York

Massari M (2011) E la giustizia che mette in mezzo le donne: il carcere, la mafia, le donne. In: Gribaudi G, Marmo M (a cura di) Donne di Mafia, Meridiana, Rivista di Storia e Scienze Sociali, n. 67. Viella, Roma

Messerschmidt WJ (1986) Capitalism, patriarchy, and crime: toward a socialist feminist criminology. Rowman \& Littlefield, Totowa

NAPTIP (2006) Annual report 2005-2006. NAPTIP Secretariat, Abuja

Nellas D (2009, February 22) Vassilis Paleokostas and Alket Rizai: Greece's most wanted men stage helicopter prison escape-again. The World Post [online]

O'Kane MJ (1992) The crooked ladder: gangsters, ethnicity, and the American Dream. Transaction Publisher, New Brunswick

Pizzini-Gambetta V (2006) Becoming visible: did the emancipation of women reach the Sicilian Mafia? In: Cento Bull A, Giorgio A (eds) Speaking out and silencing. Leeds, Maney

Pizzini-Gambetta V (2009) Women in Gomorrah. Global Crime 1(3):267-271, Routledge: Taylor and Francis

Pollak O (1961) The criminality of women. Barnes, New York

Principato T, Dino A (1997) Mafia Donna: Le Vestali Del Sacro E Dell'onore. Flaccovio Editore, Palermo

Procura della Repubblica presso il Tribunale di Napoli (2013) DDA, Comunicato Stampa, 21/1/13: clan Pianese-D'Alterio, Clan De Rosa. Procuratore Aggiunto: A. Pennasilico

Puglisi A (2005) Donne, Mafia e AntiMafia. DG Editore, Palermo

Questura di Napoli, Squadra Mobile, Informativa di reato a carico di Aiello Carmela+62, Nr.02002/ Sq.Mob.Sez.3 ${ }^{\mathrm{a}}$. Napoli, 22/5/2002

Rossi A (2007) Women in organized crime in Argentina. In: Fiandaca G (ed) Women and the mafia: female roles in organized crime structures. Springer, New York

Samuels D (2010) The pink panthers; a tale of diamonds, thieves, and the Balkans. The New Yorker 86(8):4245

Savona E, Nataoli G (2007) Women and other mafia-type criminal organizations. In: Fiandaca G (ed) Women and the mafia female roles in organized crime structures. Springer, New York

Sciarrone R, Storti L (2014) The territorial expansion of mafia-type organized crime. The case of the Italian mafia in Germany. Crime Law Soc Chang 61(1):37-60

Siebert R (1996) Secrets of life and death; women and the mafia. Verso, London

Siebert R (2003) Mafia and anti-mafia. In: Allum F, Siebert R (eds) Organized crime and the challenge to democracy. Routledge, London

Siebert R (2007) Mafia women: the affiliation of a female Pseudo-subject. The case of the 'Ndrangheta. In: Fiandaca G (ed) Women and the mafia: female roles in organized crime structures. Springer, New York

Siebert R (2011) Tendenze e Prospettive. In: Gribaudi G, Marmo M (a cura di) Donne di Mafia, Meridiana, Rivista di Storia e Scienze Sociali, n. 67. Viella, Roma

Siegel D, de Blank S (2010) Women who traffic women: the role of women in human trafficking networksDutch cases. Global Crime 11(4):436-447

Simon R (1975) Women and crime. Lexington Books, Lexington

Smart C (1977) Women, crime and criminology. Routledge, London

Steffensmeier D, Allan E (1996) Gender and crime: toward a gendered theory of female offending. Annu Rev Sociol 22:459-487

United Nations (2000) The UN convention on transnational organized crime. UNODC, Vienna

United Nations Office for Drugs and Crime (2009) A global report on trafficking in persons. UNODC, Vienna

Zaccaria AM (2011) L' Emergenza Rosa, Dati e Suggestioni sulle Donne di Camorra. In: Gribaudi G, Marmo M (a cura di) Donne di Mafia, Meridiana, Rivista di Storia e Scienze Sociali, n. 67. Viella, Roma

Zhang SX, Chin KL, Miller J (2007) Women's participation in Chinese transnational human smuggling: a gendered market perspective. Criminology 45(3):699-733 